\title{
Clinical evaluation of the use of novel and completely autologous fibrin glue during surgical procedures: Prospective open multicenter trial of the CryoSeal $^{\circledR}$ FS System
}

\author{
Masaru Shimizu ${ }^{1)}$, Nobuhiro Wakimoto ${ }^{2)}$, Masahiko Tsurumaru ${ }^{3)}$, Masaaki Usui ${ }^{4)}$, \\ Nobuya Koyama ${ }^{5)}$ and Kiyoshi Hiruma ${ }^{6)}$ \\ The CryoSeal ${ }^{\mathbb{R}}$ FS System in Patients Undergoing Preoperative Blood Transfusion Trial Group *
}

\begin{abstract}
Objective: Evaluate the clinical efficacy and safety of autologous fibrin glue (AFG) prepared by CryoSeal ${ }^{\circledR}$.
Background: Control of oozing during surgery remains an important task for surgeons. Although commercial adhesives and hospital made fibrin glue are often used to control oozing, the risk of pathogen transmission and allergic reaction cannot be completely avoided.
\end{abstract}

Methods: A multicenter, open-label, non-randomized study was conducted with 74 patients undergoing surgery with preoperative autologous blood transfusion. CryoSeal ${ }^{\circledR}$ was used to prepare autologous cryoprecipitate and thrombin from patient blood. Hemostatic effects were assessed in 62 of 74 patients.

Results: On average, $263.8 \pm 26.7 \mathrm{ml}$ of plasma was collected, and $5.3 \pm 1.2 \mathrm{ml}$ of both cryoprecipitate and thrombin were prepared. Median in vitro clotting time for AFG was 4.1 seconds (range, 1.3-195.2 seconds). The hemostatic effect against oozing was effective in 54 of 62 patients (87\%). The effective rate in patients with thrombin activity $\geq 20 \mathrm{U} / \mathrm{ml}$ was $96 \%$ (46 of 48 patients), which was significantly higher than $54 \%$ (7 of 13) in patients with thrombin activity $<20$ $\mathrm{U} / \mathrm{ml}$ ( $\mathrm{p}<0.001$, Fisher's test). Complications attributable to the use of AFG were not observed.

Conclusions: $\mathrm{AFG}$ produced by $\mathrm{CryoSea}^{\circledR}$ was prepared in a short time and clinically effective in stopping oozing. Our results show that AFG could be used for adjunct hemostasis as well as commercial adhesives and hospital made fibrin glue.

Keywords: autologous blood, fibrin glue, fibrin sealant, anticoagulant, oozing

Abbreviations: Autologous fibrin glue (AFG), autologous red cell concentrate (ARCC), Clotting time (CT), Good clinical practice (GCP), Thrombin activity (TA)

\section{INTRODUCTION}

Although surgery has advanced with recent improvements in surgical techniques and materials, achieving favorable hemostasis continues to be important in any surgical situations ${ }^{1)}$. Particularly, oozing is often difficult to manage ${ }^{2)}$, so that fibrin glue is widely used in many surgical procedures ${ }^{3)}$. Both commercial adhesives and hospital made fibrin glue are generally used. Commercial fibrin glue uses pooled human plasma and bovine aprotinin, which raise concerns

1) Kyorin University School of Medicine

2) Teikyo University School of Medicine

3) Juntendo University School of Medicine

4) Toranomon Hospital

5) Toho University School of Medicine

6) Tokyo Metropolitan Komagome Hospital

${ }^{*}$ Members of the CryoSeal ${ }^{\mathbb{R}}$ FS System in Patients Receiving Preoperative Blood Transfusion Trial Group are listed in the Appendix.

〔Received: 2008/09/05, Accepted: 2009/07/01〕 
about the risks of infection such as human parvovirus $\mathrm{B} 19^{4)}$, allogenic immunity, allergic reaction ${ }^{5 / 6)}$, and prion transmission ${ }^{7)}$. Hospital made fibrin glue is prepared at hospitals using patients' own blood for cryoprecipitate, but using thrombin prepared from pooled human plasma, which has the risks of infection ${ }^{4)}$, allogenic immunity and allergic reaction ${ }^{5 / 6)}$.

Autologous fibrin glue (AFG) is made from cryoprecipitate and thrombin using patients' own plasma. The CryoSeal ${ }^{\circledR}$ FS System can automatically prepare AFG in about 1 hour ${ }^{8)}$. AFG could have more benefits than the others. We evaluated efficacy and safety of AFG prepared by CryoSeal ${ }^{\circledR}$ in surgical departments where autologous blood transfusion and hospital made fibrin glue have been actively utilized.

\section{MATERIALS AND METHODS}

\section{Design}

The study was designed to enroll at least 60 patients at 6 medical institutions in Japan. Four departments, which are cardiovascular, gastrointestinal, orthopedic surgery, and neurosurgery, were targeted. Each department was selected from 2 medical institutions with at least 15 patients per department.

In this open-label, non-randomized study, patients were registered over a 7-month period from July 2003 to January 2004. This study wasn't designed as a comparative study using commercial adhesives because the patients wanted preoperative autologous blood transfusion intending to eliminate the risk from allogeneic blood transfusion and animal origin materials.

\section{Patients}

Patients were scheduled to undergo preoperative autologous blood collection and surgical procedures using fibrin glue. Four hundred milliliters of preoperative autologous blood was collected from patients who provided written informed consents.

\section{Device}

CryoSeal $^{\mathbb{B}}$ (Thermogenesis, CA, USA) is a device that prepares cryoprecipitate and thrombin from plasma (CS-1) with disposables of plasma processing units and applicators.

\section{Preparation and usage of fibrin sealant}

Plasma was separated from whole blood within 6 hours after blood collection and stored at $4{ }^{\circ} \mathrm{C}$ or room temperature, and then used to prepare cryoprecipitate and thrombin by $\mathrm{CryoSeal}^{\circledR}$, which were stored at $\leq-20^{\circ} \mathrm{C}$ up to the day of surgery. They were thawed at room temperature or $37^{\circ} \mathrm{C}$, and used within 6 hours to apply to the surgical site with the spray tip or the dot tip.

\section{Hemostatic effects}

Hemostatic effects of AFG were assessed as either "effective" or "ineffective". "Effective" was defined as promptly obtained hemostasis by use of AFG on the experience of conventional FG, and "ineffective" was defined as other situations that hemostasis was not obtained promptly by use of AFG, and then a patient required other additional treatments such as suture, staples and electrocautery method.

\section{Coagulation tests}

Fibrinogen contents of AFG before and after preparation were measured by clotting time $(\mathrm{CT})$, and thrombin activity (TA) by the synthetic substrate method. Using a part of each sample of AFG, in vitro CT was measured by the bead rotation method ( $\mathrm{KClA}$ micro; Sigma Diagnostics, Germany) at the test laboratory (SRL, Tokyo, Japan). CT was assessed in the following 4 grades: $<5$ seconds (quickly coagulated); 5-9 seconds (normally coagulated); 10-59 seconds (somewhat slowly coagulated); and $\geq 60$ seconds (slowly coagulated). Department, sex, total volume of donated blood, total volume of plasma used, before and after preparation of plasma fibrinogen, before and after preparation of plasma TA, CT, APTT, INR, TAT, FXIII, time of surgery, blood loss, total volume of cryoprecipitate and thrombin used were included as dependent variables for multiple logistic regression analysis.

\section{Adverse events}

Irrespective of causality, all adverse events during the study including abnormal changes in clinical laboratory tests were recorded by the investigators using the MedDRA/J classification system (version 7.1, 2004).

\section{Ethics}

The present clinical study was conducted in accordance with the Japanese Medical Device GCP (1992). The institutional review boards of each medical institution reviewed the protocol before patients were enrolled. Written informed consent was obtained from each patient before the study.

\section{Statistics}

The number of patients was determined according to the notice issued by the Ministry of Health, Labour and Welfare, "Matters concerning application for approval of medical devices" (1999). Multiple logistic regression analysis was conducted as a factor analysis for 


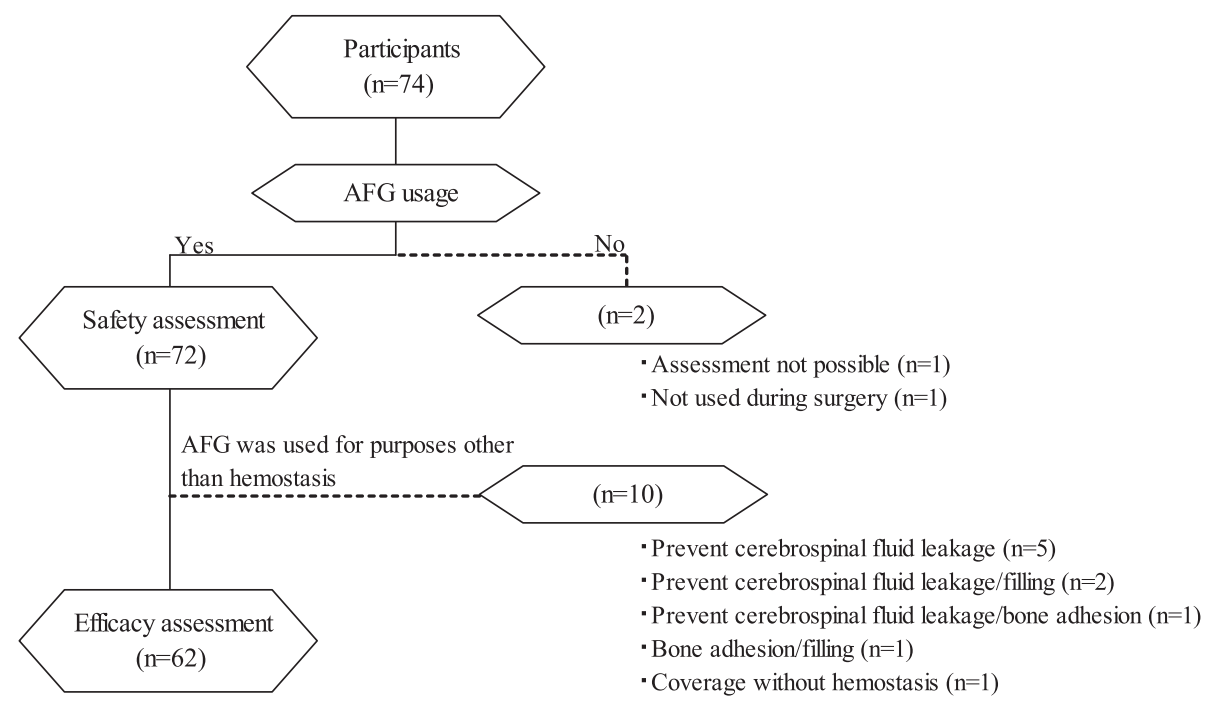

Fig. 1 Analytical flow of patients

ineffective hemostasis. Sixteen dependent variables were included at first, but 7 dependent variables were selected by variable selection method to eliminate insignificant variable until convergence. Statistical significance was assumed at a p-value of less than 0.05. A Fisher's test was used for intergroup comparison. SAS version 8.2 was used for statistical analysis, and unless otherwise noted, summary statistics were expressed as mean \pm standard deviation (SD).

\section{RESULTS}

\section{Study population}

A total of 74 patients who underwent elective surgery with preoperative autologous blood collection participated in the study (Fig. 1). The hemostatic effects of AFG prepared by the study device were assessed in 62 patients (45 men [73\%], 17 women [27\%]) except that AFG was not used in 2 patients and was used for other than hemostasis (such as stopping cerebrospinal fluid leakage) in 10 patients. Of 62 patients, 17 (27\%) underwent surgery for cardiovascular disease, 18 (29\%) for gastrointestinal disease, 18 (29\%) for orthopedic disease, and 9 (15\%) for brain disease. Characteristics of the patients are shown in Table 1. ARCC were given in $44 \mathrm{pa}-$ tients and cryo-poor plasma in 40 patients.

\section{Product characterization}

For 62 patients, mean volume of autologous blood collection was $392.3 \pm 25.2 \mathrm{ml}$ (range, $300-400 \mathrm{ml}$ ), and mean plasma volume after separation was $263.8 \pm 26.7$ $\mathrm{ml}$ (range, 205-300 ml). Mean volume of cryoprecipitate was $5.3 \pm 1.2 \mathrm{ml}$ (range, $3.0-8.9 \mathrm{ml}$ ), and the same amount of thrombin was also prepared.

\section{Hemostatic effects}

In 62 patients, AFG was used for hemostatic purposes and evaluated at 73 locations: 20 at vascular anastomosis/suture, 11 at joints, 9 at mediastinum, 5 at dura mater, 4 at gastrointestinal anastomosis, 4 at trachea, 3 each at pancreas, bone stump, and floor of the sella turcica, as well as 11 at other locations (vascular surface, bone graft/formation and bone defects). When AFG was used in 2 or 3 different locations in 5 patients, hemostatic effects in each patient were assessed in the worst outcome among the locations. Hemostatic effects were assessed as "effective" in 54 patients (87\%) and "ineffective" in 8 patients (13\%).

Multiple logistic regression analysis was conducted in 61 patients. Only TA of AFG preparations was significant ( $\mathrm{p}=0.0148$, Table 2 ). Between patients with $\geq 20$ $\mathrm{U} / \mathrm{ml}$ of $\mathrm{TA}$ and those with $<20 \mathrm{U} / \mathrm{ml}$, significant differences were seen in hemostatic effects $(p<0.001$, Fisher's test). By stratified analysis of TA, hemostatic effects of 48 patients with $\geq 20 \mathrm{U} / \mathrm{ml}$ of TA were "effective" in 46 patients (96\%) and "ineffective" in 2 patients (4\%). Of 13 patients with $<20 \mathrm{U} / \mathrm{ml}$ of $\mathrm{TA}$, hemostatic effects were assessed as "effective" in 7 patients (54\%) and "ineffective” in 6 patients (46\%) (Table 3 ).

\section{Coagulation tests}

Average fibrinogen concentration and TA in plasma in 62 patients were $286.5 \pm 72.3 \mathrm{mg} / \mathrm{d} l$ and $2.4 \pm 1.0 \mathrm{U} /$ $\mathrm{ml}$, respectively, and those values of AFG were $2,348.8 \pm 720.9 \mathrm{mg} / \mathrm{d} \mathrm{l}$ and $28.7 \pm 11.8 \mathrm{U} / \mathrm{ml}$, respectively (Fig. 2). The in vitro $\mathrm{CT}$ of $\mathrm{AFG}$ was measured in 60 patients, and median time was 4.1 seconds (range, 1.3-195.2 seconds). Hemostatic effective rate in 49 patients with 
Table 1 Demographics and preoperative characteristics of patients assessed hemostatic effects

\begin{tabular}{|c|c|c|c|c|}
\hline Characteristic & \multicolumn{2}{|c|}{ Categories } & $\mathrm{n}$ & (\%) \\
\hline \multirow{4}{*}{ Department } & & Cardiovascular surgery & 17 & 27 \\
\hline & & Gastrointestinal surgery & 18 & 29 \\
\hline & & Orthopedic surgery & 18 & 29 \\
\hline & & Neurosurgery & 9 & 15 \\
\hline \multirow{10}{*}{ Disease } & Cardiovascular surgery & Angina & 10 & 16 \\
\hline & & Aortic aneurysm & 4 & 6 \\
\hline & & Heart valve disease & 3 & 5 \\
\hline & Gastrointestinal surgery & Esophageal cancer & 18 & 29 \\
\hline & Orthopedic surgery & Knee arthropathy & 11 & 18 \\
\hline & & Spondylopathy & 4 & 6 \\
\hline & & Hip arthropathy & 3 & 5 \\
\hline & Neurosurgery & Brain tumor & 4 & 6 \\
\hline & & Brain aneurysm & 3 & 5 \\
\hline & & Arterial stenosis/occlusion & 2 & 3 \\
\hline \multirow{2}{*}{ Gender } & & Male & 45 & 73 \\
\hline & & Female & 17 & 27 \\
\hline \multirow{4}{*}{$\begin{array}{l}\text { Age } \\
\text { (years) }\end{array}$} & & $20-39$ & 2 & 3 \\
\hline & & $40-59$ & 24 & 39 \\
\hline & & $60-79$ & 36 & 58 \\
\hline & & Mean $( \pm \mathrm{SD})$ & \multicolumn{2}{|c|}{$61.5( \pm 10.0)$} \\
\hline \multirow{4}{*}{$\begin{array}{l}\text { Body weight } \\
\text { (kg) }\end{array}$} & & $30-49$ & 10 & 16 \\
\hline & & $50-79$ & 48 & 77 \\
\hline & & $80-99$ & 4 & 6 \\
\hline & & Mean $( \pm \mathrm{SD})$ & \multicolumn{2}{|c|}{$61.6( \pm 11.6)$} \\
\hline \multirow{5}{*}{$\begin{array}{l}\text { Fibrinogen } \\
(\mathrm{mg} / \mathrm{d} l)\end{array}$} & & $100-199$ & 2 & 3 \\
\hline & & 200-399 & 43 & 70 \\
\hline & & $400-699$ & 17 & 27 \\
\hline & & Mean ( \pm SD) & \multicolumn{2}{|c|}{$349.0( \pm 109.2$} \\
\hline & \multicolumn{2}{|l|}{ Total } & \multicolumn{2}{|l|}{62} \\
\hline
\end{tabular}

Table 2 Multiple logistic regression analysis

\begin{tabular}{lccc}
\hline \multicolumn{1}{c}{ Parameter } & OR & OR 95\% CI & p-values \\
\hline Fibrinogen conc. in plasma & 0.988 & $0.970-1.006$ & 0.1947 \\
APTT & 1.225 & $0.927-1.619$ & 0.1545 \\
TAT & 1.131 & $0.888-1.442$ & 0.3186 \\
Thrombin activity & 1.220 & $1.040-1.431$ & 0.0148 \\
Time of surgery & 0.997 & $0.989-1.005$ & 0.4194 \\
Total blood loss & 0.997 & $0.993-1.001$ & 0.1972 \\
Amount of AFG used & 1.333 & $0.819-2.169$ & 0.2477 \\
\hline
\end{tabular}

Odds ratio and p-values were calculated using multiple logistic regression analysis measuring ineffective hemostasis. Results were considered significant at p-values less than 0.05 . OR: odds ratio

CI: confidence interval

APTT: activated partial thromboplastin time

TAT: thrombin-AT-III complex

AFG: autologous fibrin glue

CT $<10$ seconds was $92 \%$ (45/49) compared to $70 \%(7 / 10)$ in 10 patients with CT 10-60 (Table 3). Although in vitro CT could not be measured in 2 patients due to clots in the samples, AFG was used during surgery, and hemostatic effects were assessed as effective in one patient, and ineffective in the other. The patient with the longest CT (195.2 seconds) showed enough hemostatic effect, in spite of clot formation in the preparation which has $2,750 \mathrm{mg} / \mathrm{d} l$ of fibrinogen and $12.8 \mathrm{U} / \mathrm{ml}$ of $\mathrm{TA}$.

\section{Adverse events}

No complication defined to relate to AFG administration was observed. No adverse reaction such as vasovagal reactions was observed during autologous blood donation.

\section{DISCUSSION}

In Japan, hospital made fibrin glue has been prepared using autologous cryoprecipitate, and used as a hemostatic agent and adhesive in surgery for long. However, pooled human plasma is used as the raw material of thrombin, and the infection risk is not completely avoided. Because commercial adhesives contain fibrinogen and thrombin made from pooled human plasma and use bovine aprotinin, they cannot exclude the risk of prion transmission. Moreover, it has been 
Table 3 Clinical hemostatic effect of AFG based on thrombin activity and in vitro clotting time

\begin{tabular}{|c|c|c|c|c|}
\hline & $\mathrm{n}$ & Effective & $\begin{array}{l}\text { Effective } \\
\text { rate }(\%)\end{array}$ & Ineffective \\
\hline \multirow{2}{*}{ Thrombin activity* $(\mathrm{U} / \mathrm{m} l)$} & 61 & & & \\
\hline & 2 & 2 & 100 & 0 \\
\hline $40-49.9$ & 9 & 9 & 100 & 0 \\
\hline 30-39.9 & 19 & 18 & 95 & 1 \\
\hline $20-29.9$ & 18 & 17 & 94 & 1 \\
\hline $10-19.9$ & 9 & 5 & 56 & 4 \\
\hline$<10$ & 4 & 2 & 50 & 2 \\
\hline \multirow{3}{*}{$\begin{aligned} & \text { Clotting time }^{\dagger} \text { (seconds) } \\
&<5 \\
& \geq 5 \text { and }<10\end{aligned}$} & 60 & & \multirow{3}{*}{92} & \\
\hline & 36 & 33 & & 3 \\
\hline & 13 & 12 & & 1 \\
\hline$\geq 10$ and $<60$ & 10 & 7 & 70 & 3 \\
\hline$\geq 60$ & 1 & 1 & 100 & 0 \\
\hline
\end{tabular}

*: Thrombin activity was not measured in one patient due to clots in the sample.

$\dagger$ : Clotting time was not measured in two patients due to clots in the samples.
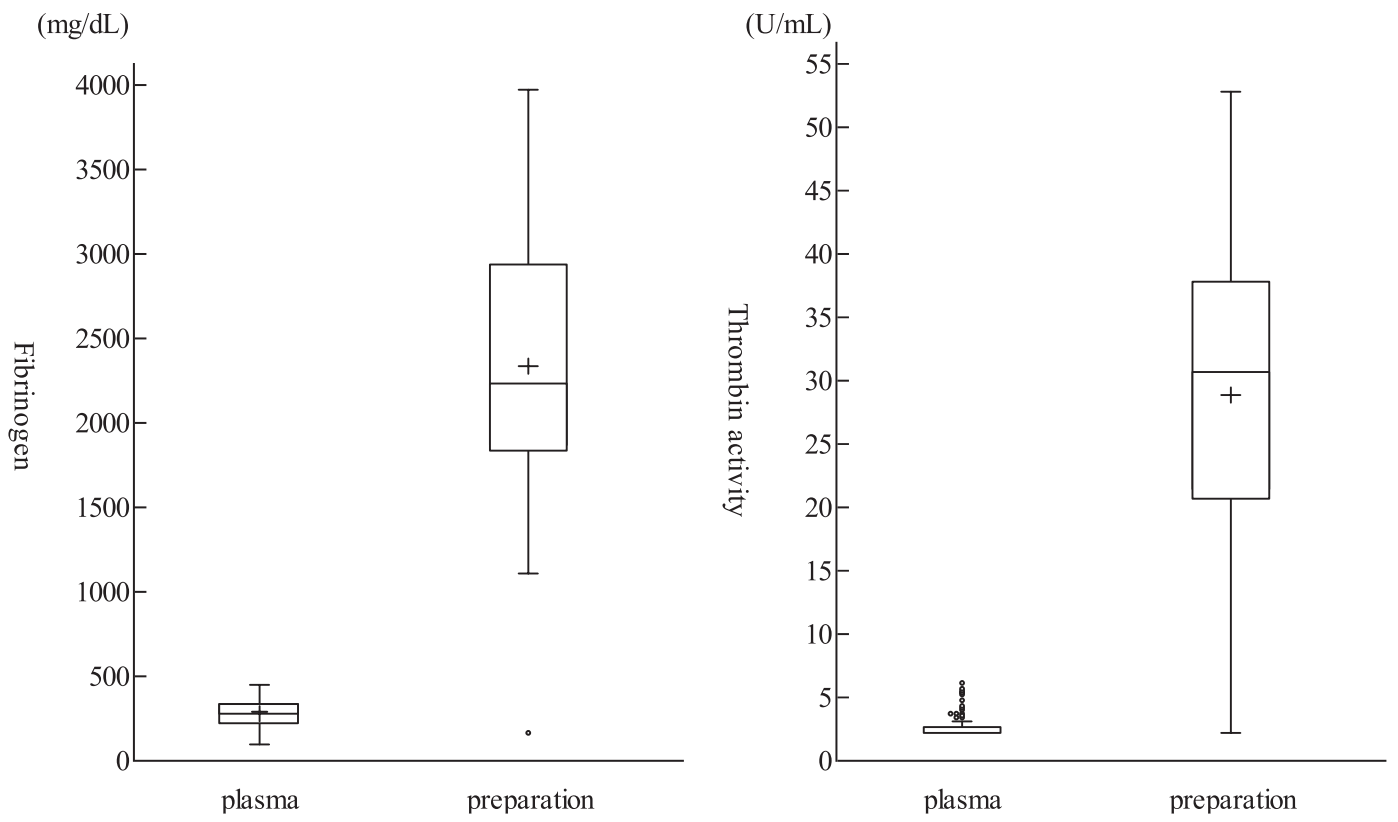

Fig. 2 Fibrinogen concentrations and thrombin activity in plasma and preparation

concerned recently that a group of patients in Japan may have been infected with the hepatitis $\mathrm{C}$ virus through fibrin glue prepared from contaminated fibrinogen products. In addition, allergic reactions can occur in rare occasions ${ }^{5}$, and a patient died of anaphylactic shock was reported ${ }^{6)}$.

Thrombin activity (TA) of AFG $(28.7 \pm 11.8 \mathrm{U} / \mathrm{ml})$ in the present study was lower than that of commercial adhesives (250-500 U/ml) or hospital made fibrin glue (500-1,000 U/ml). According to in vitro data obtained by Yoshida et al., adhesive strength reached a peak at $50 \mathrm{U} / \mathrm{ml}$ of $\mathrm{TA}$, and actually decreased as TA in- creased $^{9)}$. Furthermore, other studies have reported that clotting time $(\mathrm{CT})$ reached a plateau at $>20 \mathrm{U} / \mathrm{ml}$ of $\mathrm{TA}^{10)}$. In the present study, the effective rate of AFG was $87 \%$ overall, and $96 \%$ (46 of 48 patients) in patients with $\geq 20 \mathrm{U} / \mathrm{ml}$ of $\mathrm{TA}$ after preparation was effective compared to $54 \%$ (7 of 13 patients) with $<20 \mathrm{U} / \mathrm{ml}$ of TA (Table 3). Moreover, the thrombin generated by CryoSeal ${ }^{\circledR}$ showed comparable activity with commercial thrombin by thromboelastograph measurements ${ }^{11)}$. This suggests that TA of AFG is not necessary to be as high as that of commercial adhesives or hospital made fibrin glue. The effective rate for commercial ad- 
hesives in similar clinical studies was ranged from about $83 \%$ to $97 \%{ }^{12) 13}$, suggesting that the efficacy of AFG in the present study is comparable to that of commercial adhesives. The FDA (Food and Drug Administration) has recently approved CryoSeal ${ }^{\circledR}$ as adjunct for hemostatic purposes in patients undergoing liver resection. This supports our result because a resected liver is a representative of oozing surface resisting hemostasis.

The hemostatic effects of AFG are influenced not only by AFG activity, but also surgery-related factors. In the present study, $\mathrm{AFG}$ was thawed at either $37^{\circ} \mathrm{C}$ or room temperature and used within 6 hours. Since it is reported that the TA of AFG was affected by the time after thawing and storage temperature ${ }^{10}$, further investigations remain to be resolved. With regard to side effects, none was attributable to $\mathrm{AFG}$ in this study.

In conclusion, CryoSeal ${ }^{\circledR}$ is capable of preparing autologous thrombin and cryoprecipitate from a single unit of plasma in a short time within a closed sterile system. Favorable hemostatic effects were obtained for oozing, and blood collection process was safely performed. Furthermore, because there is no risk of infection or allogeneic immunity, AFG prepared by CryoSeal ${ }^{\circledR}$ could be used as well as commercial adhesives or hospital made fibrin glue in surgery in the future.

\section{ACKNOWLEDGEMENTS}

This clinical study was conducted with financial and technical assistance from Asahi Kasei Kuraray Medical Co., Ltd. (Tokyo, Japan).

\section{APPENDIX}

Participants in this clinical study team were as follows: $\mathrm{Dr}$. Fumiyuki Okamoto, Teinekeijinkai Hospital, Sapporo, Japan; Drs. Shintaro Tachibana and Michio Matsuzaki, Toranomon Hospital, Tokyo, Japan; Dr. Akimichi Ohsaka, Juntendo University School of Medicine, Tokyo, Japan; Drs. Yosuke Izumi and Osamu Nakamura, Tokyo Metropolitan Komagome Hospital, Tokyo, Japan Dr. Akira Ohara, Toho University School of Medicine, Tokyo, Japan; Dr. Koki Takahashi, The University of Tokyo, Tokyo, Japan; Dr. Hisami Ikeda, Hokkaido Red Cross Blood Center, Sapporo, Japan; and Dr. Masashi Taki, St. Marianna University School of Medicine, Kawasaki, Japan

\section{References}

1) Spence RK, Mintz PD: Transfusion in Surgery, Trauma, and Critical Care. In: Mintz PD, ed, Transfusion Therapy: Clinical Principles and Practice, 2nd ed, AABB press, Bethesda, 2005, 203-241.

2) Krayenbühl N, Hafez A, Hernesniemi J, et al: Taming the cavernous sinus: technique of hemostasis using fibrin glue. Neurosurgery, 61: ONS-E52, 2007.

3) Spotnitz WD, Prabhu R, Welker R, et al: Clinical Uses of Fibrin Sealants. In: Mintz PD, ed, Transfusion Therapy: Clinical Principles and Practice, 2nd ed, AABB press, Bethesda, 2005, 437-477.

4) Hino M, Ishiko O, Honda $\mathrm{K}$ : Transmission of symptomatic parvovirus B19 infection by fibrin sealant used during surgery. Br J Haematol, 108: 194-195, 2000.

5) Beierlein W, Scheule AM, Antoniadis G: An immediate, allergic skin reaction to aprotinin after reexposure to fibrin sealant. Transfusion, 40: 302-305, 2000.

6) Oswald AM, Joly LM, Gury C, et al: Fatal intraoperative anaphylaxis related to aprotinin after local application of fibrin glue. Anesthesiology, 99: 762-763, 2003.

7) Farrugia A, Ironside JW, Giangrande P: Variant Creutzfeldt-Jakob disease transmission by plasma products: assessing and communicating risk in an era of scientific uncertainty. Vox Sang, 89: 186-192, 2005.

8) Zucchelli P, Silvestri AR: Production and use of fibrin glue at blood transfusion service of Bellaria-Maggiore Hospital Bologna. Transfus Apher Sci, 30: 157-161, 2004.

9) Yoshida H, Hirozane K, Kamiya A: Adhesive strength of autologous fibrin glue. Biol Pharm Bull, 23: 313-317, 2000.

10) Kumar V, Madsen T, Zhu H, et al: Stability of human thrombin produced from $11 \mathrm{ml}$ of plasma using the thrombin processing device. J Extra Corpor Technol, 37: 390-395, 2005.

11) Rock G, Neurath D, Semple E: Preparation and characterization of human thrombin for use in a fibrin glue. Transfus Med, 17: 187-191, 2007.

12) Kohama G, Yamamoto E, Asakura A, et al: Clinical study of heated human fibrin glue (Tisseel ${ }^{\mathbb{R}}$ ). Kiso to Rinsyo, 21: 279-288, 1987. Japanese.

13) Shimosawa E, Nakajima K, Kato H, et al: Result of the clinical study of the usefulness of fibrin-adhesives (Beriplast ${ }^{\mathbb{R}} \mathrm{P}$ ) in multiple institutes. Shinryo to Shinyaku, 32: 367-378, 1995. Japanese. 


\title{
CryoSeal ${ }^{\circledR} \mathrm{FS}$ システムによる全自己フィブリン糊を外科手術時の止血補助に 使用した多施設共同一般臨床試験結果
}

 \\ 比留間 潔 ${ }^{6)} \quad$ The CryoSeal ${ }^{\circledR}$ FS System臨床試験グループ* \\ ${ }^{1}$ 杏林大学医学部附属病院 \\ 2) 帝京大学医学部附属病院 \\ 3) 順天堂大学医学部附属順天堂医院 \\ ${ }^{4)}$ 国家公務員共済組合連合会虎の門病院 \\ 5) 東邦大学医学部付属大森病院 \\ 6) 東京都立駒込病院 \\ ${ }^{*}$ CryoSeal ${ }^{\circledR}$ FS システム臨床試験グループは Appendix に記載
}

\section{要旨:}

目的：CryoSeal ${ }^{\circledR}$ で調製した全自己フィブリン糊の臨床での有効性と安全性の評価.

背景：外科手術時の滲出性出血コントロールは依然として外科医にとって重要な課題である。医薬品や用手法の フィブリン糊が止血剤として頻用されているが, 病原体伝播やアレルギー反応等の可能性は完全には否定できない.

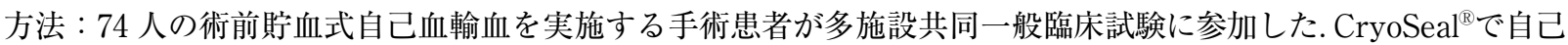
クリオプレシピテートと自己トロンビンを調製し, 74 人のうち 62 人が止血効果を評価しえた.

結果 : $263.8 \pm 26.7 \mathrm{ml}$ の血漿からそれぞれ $5.3 \pm 1.2 \mathrm{ml}$ の自己クリオプレシピテートとトロンビンが調製できた. In vitro での凝固時間の中央值は 4.1 秒（範囲 1.3 195.2 秒）であった． 渗出性出血に対する止血効果は， 62 人のうち 54 人 $(87 \%)$ で良好であった。 トロンビン活性が $\geqq 20 \mathrm{U} / \mathrm{ml}$ の患者の良好率が $96 \%$ （46人/48人）であったのに対 し， <20U/ml の患者の良好率は $54 \%$ (7 人 $/ 13$ 人) であり，止血効果に有意な差が認められた $(\mathrm{p}<0.001 ，$ Fisher’s test). 全自己フィブリン糊によると考えられる合併症は認められなかった.

結論：CryoSeal ${ }^{\circledR}$ は全自己フィブリン糊を短時間で調製でき, 外科手術時の止血補助に有効であった. 我々の試験 結果は，全自己フィブリン糊は医薬品や用手法フィブリン糊と同様に外科手術時の止血補助に利用できることを示 している.

キーワード :

自己血，フィブリン糊，フィブリン接着剤，抗凝固剤，滲出性出血

(C)2009 The Japan Society of Transfusion Medicine and Cell Therapy Journal Web Site: http://www.yuketsu.gr.jp 